\title{
Conversations with Two Canadian Film Artists
}

\author{
By Gerald Pratley
}

Spring 1994 Issue of KINEMA

\section{MICHELINE LANCTÔT AND COLM FEORE TALK TO GERALD PRATLEY}

(1) MICHELINE LANCTÔT wrote and directed wrote and directed wrote and directed Deux Actrices (Two Can Play), with Pascale Bussières, Pascale Paroissien, Louise Latraverse, François Delisle, Suzanne Garceau; a drama of re-conciliation between two estranged sisters, the charm and intrigue of which soon becomes a nightmare, with the actual narrative being interspersed with real-life scenes of the two actresses at work. ${ }^{(1)}$

Pratley: Ms. Lanctôt, what inspired you to film this subject in a somewhat unusual way?

Lanctôt: It came about from an idea I had a long time ago. I teach "Directing Actors" at Concordia University in Montréal -- I always had trouble explaining what "character" is on a screen to my students, and how actors approach a character. And I had long been tempted by the notion of doing something involving an actor and his character to try -- not to illustrate or demonstrate -- but just get the feeling of what the relationship is between an actor and a character. That was 10 years ago. And then in one of my classes I had this woman, who was a student of mine, whose face was very interesting, and the idea came to me that I should put her in the same film with Pascale Bussières and that I should involve them as actresses. It evolved pretty much from that woman and the idea of a character that she gave me and the situation that came out of it. The film was set up very, very quickly. I hammered out a screenplay -- a very tentative screenplay in about a week, I think, with lots of dialogues then completely ejected from the film. I wanted to make the film like a notebook, without any preparation -- no financing, nothing at all.

I contacted everybody I could think of. I had a lot of help from my Concordia students -- they were instrumental, actually, in having the picture set up, because they offered me their unlimited support, and so I said "Yes." And I felt confident -- I wouldn't have done it by myself, it would have been too hard. But knowing that I had a great deal of support from about 10 students of mine I like very much, I put everything together within a matter of weeks and we started shooting very quickly -- with my money.

I noticed in the credits at the end there was no reference to Telefilm.

Nothing. It was done outside of these.

Did you send them the script?

No. I didn't want to. Because for years I've been fighting this bureaucracy and also these hidden restrictions they have in Québec that directors cannot be producers. Which is absurd because it happens in the rest of Canada but not in Québec. It's a notion that I decry. They don't want the producers and the directors to be the same person. And I've been arguing with them for at least a good ten years over that. All the projects I had initiated and started producing were eventually shelved because I couldn't find a producer.

I wanted to prove to them that I could produce my own films, within a very limited scale -- in which I like to work. I like working with constraints -- I find them creative. And I said I'm not going to make a film with them. I asked the Arts Council for a grant and started the film without even having the answer. Fortunately they came, though five months later, and that allowed me to finish the film.

Your structure is very interesting. There's a part with the actresses talking about playing the parts, filmed in video...

In Hi-8, yes -- I had the Hi-8 material transferred on $16 \mathrm{~mm}$.

It's come out very well. Is it possible that you could have shot the whole thing on Hi-8 and transferred it to 16 ?

Oh, yes. It's eminently possible.

But you didn't do that.

No, because I wanted to use both techniques to differentiate the work in progress -- their rehearsal situation 
-- with the actual fiction, with the story part of the film. And I felt that it was important that the spectator had a reference; otherwise it would have been too confusing. I don't know if it really does serve as a reference, but I think it's like a natural border and then I apply myself to erase that border [laughs]. The fiction -- the story part of it was shot over a period of 16 days. And the rehearsals were done in four days.

That's remarkable, because it looks so professional. If one didn't know anything about technical matters one would assume it was made as any other film, with time and money. Lately there are very few Canadian films made for under 3 million dollars and they don't look like 3 million dollars.

No, and it's a shame, because that comes from the institutional policy of building up a private industry. And you and I both know there's no chance of a private industry in Canada; it's owned by the Americans anyway. And attempting to establish a private industry is contrary to reason. It's a state business and Telefilm acts as a state producer. Although it doesn't want the credit or the responsibility it acts as a major. The tragedy is that the films don't pay, that they cannot get money back in any way, that all this pretence of a private industry falls very short of reality. I was always very sensitive about that; I don't like wasting money. It's my nature. To me, if I lose $\$ 40,000$ on a film it's my money, I can lose it. I stand a chance of regaining it in another way, but I don't like making a film for four million knowing it won't even recoup $\$ 50,000$. And yes, it provides jobs, but I think there are other ways to make films than providing jobs for gaffers and cable-pullers on American productions and still be properly treated and have decent salaries.

Why shouldn't our films cost a minimum? Because we know there's no market for them; there's no way these Canadian films make money. They cannot in the actual system of exhibition. That's always been my position. I was always very confronted with that issue. Either it's a state cinema, and everybody has a chance every five years to make a film and we get paid a salary, or it's a private industry and the majors take over and we make films with the Americans. But not that kind of asinine solution of providing jobs for people and having the films die at the box-office because all the money goes back to the States. I know there are no ideal solutions, but personally for me, I find dealing with smaller budgets much more creative and I can claim it as my own, and my own only. And if it's bad, I only have me to blame [laughs]. I think that's fair.

Roger Frappier has called for changes to SOGIC. That there should be another organization financing film and TV. Did anything happen?

Well, yes. The Minister of Culture for Québec has a project for a new funding system on the provincial level. SOGIC is a perfect failure, it doesn't work. It's now a place for political appointees who have no contact whatsoever with the milieu. Their decisions are eminently controversial. They turned me down on almost all the projects that I've brought to them; I don't mean to say that that makes them meanies, but they have made very disputable choices. They have no money -- or very little money and half of it goes into organizing lots of travels for lots of people all over the place. We don't know what goes on, we don't have access to them; it's a perfectly governmental agency very unpopular with the Québec filmmakers.

And so the profession demands changes, and the Minister of Culture has a plan to establish her cultural policy. She drafted this whole cultural thing to involve local arts councils and a special centre for cinema which would get rid of SOGIC and install a new funding system. How we don't know. We have an election coming up, and yes, we expect major changes. I don't care really who goes into power; I stopped caring about local politics a long time ago, I just want the organization to change. SOGIC is a real failure as far as helping the filmmakers is concerned. It's done nothing but ruin films. It is so heavy-handed, so secretive, so remote from the people who work in cinema that it has to go. It really has to go.

Do you think another government would continue to do this?

If the Parti Québécois comes into power, traditionally they have always been closer to the cultural milieu than the Liberal Party. Whenever we have requests we deposit them with the opposition, and so the Liberals are perfectly aware of our needs and our requests as far as financing cinema. Of course, they never have any money, so that's a major problem -- they have to split one penny into a thousand shares. We have been begging them to raise the ceiling on the funding for SOGIC, but they haven't done it -- the Liberal Party hasn't done it.

Back to your film. You did everything on location. Was that someone's house? 
That was Pascale's apartment. I just rearranged some things quickly, but it was pretty much the way it was with her furniture, her clothes. I had very little choice in the matter, my mise-en-scène consisted of putting the camera in the corner at a very low angle, and saying "Let's go." There was very little I could do, I had only a tripod; I had nothing to move the camera with.

Must it take a year to write screenplays then, given what you've done?

The American way it takes a year, because you're always catering to everybody's whims. Everybody wants it rewritten. That happens in Canada too. Half of the time they say, "We don't like the beginning, we don't like the end." No two persons like the same thing, so what do you do? You start listening to everybody, you go crazy. They really want a foolproof story. There's no such thing, a film is made by images; yes, you need a structure, you need a story, but I've become very wary of screenwriting. You end up thinking in words when you should be thinking in images. Images is the rhetoric of the cinema, not words.

I find by putting so much emphasis on a script they all want TV things: they all want characters who are sympathetic, they all want us to explain about the characters. You don't -- cinema doesn't do that. I get very impatient, I didn't want my film to go through that. I had one film stuck in there for six years, you know. Again, "Change this, change that, change ..." I'm thought not to listen to anybody. I'm considered headstrong, I'm not obliging anybody. Well, no, I don't want to oblige anybody; I know what I'm doing. If the show is unsuccessful, it's my problem. I am hoping that my film will inspire more people to try on their own. We have to wean ourselves from the bureaucrats. They get so powerful, and they have us ... and most people just wait at the door, wait and complain and mourn, and wait at the door. We have to do something. Of course, doing that, we play exactly into their hands, because then they turn around and say, "See, they did it without us, they don't need us." I must say however that Telefilm Canada paid for a print with subtitles because the film was invited to both the Vancouver and Toronto Film Festivals. And so they asked for Telefilm to subtitle a print, and they did.

(2) COLM FEORE portrays pianist Glenn Gould in Thirty-Two Short Films About Glenn Gould, written by Don McKellar and François Girard, and directed by Girard. ${ }^{(2)}$ This is not a biography resembling in any way the usual screen biography of individuals, artistic or otherwise. Instead, realising from the beginning that the life and character of the idiosyncratic pianist would be almost impossible to portray in an inexpensive documentary-like study, the writer, director, producer and actor have created on film a work which is entirely in keeping with what Gould did with music.

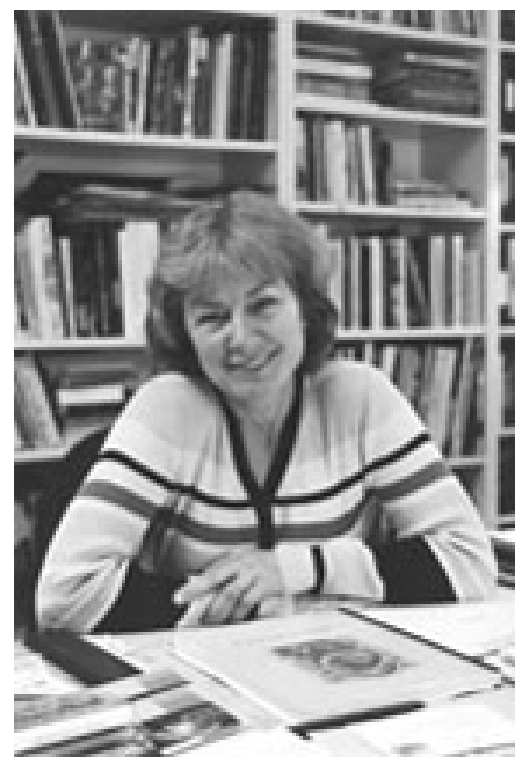

Figure 1: Actress and filmmaker Micheline Lanctôt 
Pratley: I know you've had a great many interviews about the film ...

Feore: Not many; you'd be surprised, because it's come out in so many festival settings before general release, and my schedule has been horrific, I wasn't looking forward to doing much until we're actually at the time of general release, which won't be for a while. So I haven't exhausted all the possibilities or bored myself with repetition yet.

\section{How were you chosen for this role? Did you know Glenn Gould?}

No, only through his music. Ironically it turns out that he was, in fact, music director of the Stratford Festival for three years during its early stages, but that was as close as we got. How the film came to me? The producer had been searching for some time for someone to play it, and had, understandably, grave reservations about casting the role because once they'd done that, as you've seen, they were stuck. So François Girard, producer Niv Fichman, and the casting director Deirdre Bowen came to Stratford and they saw half a play -- I was playing Mercutio in Romeo and Juliet. They waited until I died and then we all went to dinner. And at that point we discussed the possibility of my doing it, but only in very vague terms, and I think it was up to me to audition, however eccentrically, for it over dinner. Which I did, and then we went on and auditioned again and after weeks of this, François was satisfied I could do what he required of me. So, we went ahead.

\section{As an actor, what did you think about the shape of the film?}

Well, I thought it allowed for an enormous flexibility. I think that François' vision of it was one of evocation and impressions rather than imitation and a strict chronological biography. And indeed, one wouldn't have had enough time for that; it would have been double the length, and you still wouldn't have been any closer to the man, I don't think. They scripted many more films than we put in to give them options, and I think they chose the best of what they were left with.

I felt the very structure allowed us a scope imaginatively, where even the almost documentary interview of individuals took on -- because of the nature of what they say -- a narrative element. It's more than just a "talking head," it has something -- the little kernel of experience that they offer is much more than simple "And then he did this, and he went there." They had some insight -- knowing him reasonably well -- into him and so the distillation of their experience into one brief moment carried, I believed, a great deal more weight. And I rather liked the way it was then structured because you can't pin him down -- one of the pieces is "Questions with No Answers" -- and I think the whole film falls in that realm. There are indications, there are impressions, there are suggestions, and as Gould himself wrote, "Fiction would be the best biography." And we took him at his word. Everything that's represented in the film has a basis in factual reality, but the scenario that supports it is fictionalized. Seeing it now, I don't see any other way to do it.

Several sequences where people are asking you questions -- I thought I'd like to hear some answers.

But that's the point, there really aren't any. We pored over all the materials, in print and in film and television, and in the music looking for these kinds of answers, and the closest we got to anything like that was in the National Archives, where a letter to "Dell" -- an anonymous person really, or an obviously madeup name for someone -- was found, as well as an unfinished personal ad. It then became a question of going backwards from that and trying to surround it with a dramatic structure, you know, "Well, when did this get created, when did he do this?" As for putting a period to these questions and actually getting a serious answer, anything we could have done would have been speculative, and I felt that it was not up to us to lead the audience in any particular direction but rather that they should be left with a clarified, but no less unanswered view of what the questions are about him.

I think François managed to handle this in a very delicate and rather touching way in that they're questions that People magazine might ask, and indeed the interview with a particularly horrible woman is taken from People magazine transcripts. So he did have to endure these things, but never really came up with any answers that were sufficiently clear and distinct that could be plastered up on the fridge, and say "This is what Glenn Gould is" and "that is what he is." One of the real advantages to this ambiguity is that it forces us to look at what is extant: well, the music, his writings, and some brief biographical information. But we really have to deal with him the way he wanted us to deal with him, which was through the electronic media he left behind. I think he's hovering in the ether very closely above us chuckling away, thinking Ha! 
That's all they've got left isn't it? They'll have to mine that now, and see what they can come up with." He might say, "It doesn't matter about me; I don't matter." I'm getting like him again! But, I'm not important -- what was produced -- the music -- is important, but how you respond to the music in an individual way in the privacy of your own home, where you can adjust all the knobs, the bells and the whistles and create your own concert environment, is far more important than whether or not I had turnips for breakfast -- and who I had breakfast with.

You seemed to spend far more timed finding out about Glenn Gould than you did playing him. Oh, yes, there's no question. François and I did an enormous amount of research -- some of it very straightforward, a lot of it very odd, from simply poring over videos and his writings, to wandering around the lake at Stratford dressed as him, and lying under pianos at the Conservatory in downtown Toronto, kicking them, and sort of saying, "What sound does that make?" and "What happens when the actor moves here?" and "Why don't we just look at this Baldwin grand or Steinway grand for a moment and just get the smell of it."

And we did an enormous amount of work before we shot a single foot of film, partly because we didn't have a lot of film; we didn't have a lot of money. It was imperative that we get the most out of the little we had, so we rehearsed and rehearsed given the ridiculous schedules I had. François would drive to Stratford and he'd stay with me a day or so; I'd come into Toronto if I had a day off and we'd do the same kind of work there. At the end, we developed a palette of possibilities that he could draw from for any given film: "Would you like the movement this extreme?" "Where is your camera?" "What's the lens?" "If we don't do enough of this, then when we get closer we won't have that." "What about the diction -- his rather over, self-aware way of speaking. We should have a real range of possibilities so that you as director can pick up what suits this particular scene. So we went at it that way."

\section{Did you film all your sequences at one time?}

No. I was very delighted to find that they were agreeable to working around my schedule which meant Mondays -- it's the only day we get off at Stratford -- and whatever days came free by happenstance, because of the scheduling. Then we did about seven or eight days straight after the season had finished; it was all over the place -- it was the only way to do it.

\section{It's remarkable that you didn't lose the feel for the part.}

Well, I must confess that I was at the end of the Stratford season, so I was bidding it farewell in one way or another anyway. The danger was that occasionally Glenn made an appearance as Mercutio which wasn't very good, and it was difficult to get rid of him because I spent most of my free time trying to inhabit him. As you see, I never touch a piano, because we felt it was just gravely insulting; that was his piano -- 318. One of the fellows who was interviewed later on said he felt this way too, getting that piano back from Ottawa where it was on display at the National, tuning it up and getting it working again. Everything was his, the gloves, certain bits of costumery were his -- it was really quite a remarkable thing, trying to become him. We felt that if we did sit down and do pretend piano playing -- there's nothing worse really, you've seen those old Hollywood biographies about the great piano players and composers, and you see these actors bobbing their heads slightly out of time -- and they cut to some hands -- and they're somebody else's hands, and it's all disagreeable. No, we thought that would be an insult to the great man's memory. Neither could we say, "let's get somebody who can actually play the stuff," because no pianist who could play as well as Glenn Gould would want to be involved in a film about Gould rather than one about themselves, it seemed to us.

So why not think of something imaginative that would allow Glenn to speak for himself, which is what the underscoring of all the music does -- it's all him. This is very necessary because in terms of narrative structure, clues about the man are important and his music was an enormous one in terms of understanding him. As actors, when we're looking at parts and characters in great plays, you think "How am I going to re-embody and re-invent this person?" Well, you have the actions that are very clearly delineated on the page, and you say, "What kind of man is it who does A, B, C and D?" The same applied here: if you had that string quartet with that music -- that very melancholy, yearning, stretched-out music -- what kind of a man in what state of mind would write something like that? Coming as it does at that moment in the film, tells us then a great deal about who he was, how he felt, and explains then, from that point, both before and after, some of his relationships. Some of the women who say he called and then stopped, he was frustrated and he stopped. Another playwright, I believe, asks him a direct question: "Weren't you just afraid? Is that 
why you retreated to this electronic world?" He then very wisely said, "Often when people make these kinds of decisions, they have to exaggerate the moral justification for it by making it a universal point, when in fact it's really quite a personal one." So I think he was guilty of a little of that.

I'm interested in the backgrounds, for example in the house as a boy -- was that really the house?

If it wasn't the exact house, it was the one next door that remained more to period. It was at Lake Simcoe and indeed very much like the original house. The furnishings were very similar and that was his favourite piano, it had a quite tinny, harpsichordian touch and sound to it, and that was the one he practised on most. He demanded much the same kind of response from his Steinways; he would cause people enormous trouble over that.

And it wasn't actually his car, but it was precisely the same kind of car. He called it "Longfellow," that great big Lincoln Continental, and would get into terrible accidents, he was such a very bad driver. He drove around conducting and listening to Petula Clark and all that kind of stuff.

No, the restaurant where I overheard all the conversation, was not one that he frequented. This is where we have an imaginative leap given the fact of the radio documentaries, given the history of the lead up to them and Gould's writings on the subject, believing that like little musical pieces with contrapuntal this and that, he believed that as at cocktail parties and receptions, we could hear far more than just one voice, and that's certainly how he played. So he simply went a step further; and we went another step further and said, "Well, if he got that idea, here's a place where it might have come to him. It's like "my first American dollar; my first five-dollar bill." But if you notice just prior to that shot, there's the reverse of them coming up the hill, which says "Toronto 20 miles," so they're within striking distance. The LA concert? He did sign one or two last programs. And that was the last concert, so it's simply an imaginative reconstruction of that last evening where he decided to give it up forever. The scene where he was listening to the playback of his recording with the three technicians was filmed in a converted church in Toronto at Pape and Danforth, a wonderful place remodelled and beautifully designed to resemble almost exactly the CBS recording studios at 30th Avenue in New York. It could have been expensive but the church was on loan

to a variety of worthy community events, and as we didn't disrupt that particular stuff much, we were allowed to go ahead and take it over for a couple of weeks. The ice scene was done on the St. Lawrence in the middle of January near Trois Rivières du Lac, which is just an hour or two up the road. In the middle of January -- no, it was horrible. I mean, I had a radio in my pocket, and I was told, "Start walking." "Carry on." So that's how that was done.

It was a striking beginning because it showed how distant and alone he was --

....and indeed, how dead he is. There he is coming back to introduce himself to us. And for those people who don't know him at all, one has to say, "Well, gently, gently, gently." François takes a couple of films before he introduces me, close, and 45 seconds in a chair. People say, "Oh, we've seen this creature coming in from the white beyond, from nowhere," and indeed after that voyage we return him, we send him back.

(These interviews took place at the Rouyn-Noranda Film Festival.)

\section{Notes}

1. Micheline Lanctôt has also directed The Handyman (80), Sonatine (83), La poursuite du bonheur (87), Onzième speciale (88); and has appeared in The True Nature of Bernadette, The Apprenticeship of Duddy Kravitz, The Coffin Affair, Mourir à tue-tête, among others.

2. François Girard has directed many Canadian documentaries and television films, notably the awardwinning Le Dortoir. Colm Feore made his name at the Stratford (Ont.) Shakespearean Festival in such diverse roles as Oberon (A Midsummer Night's Dream), Dyonisos (Bacchae), John Worthing (The Importance of Being Earnest), Mercutio (Romeo and Juliet), Berowne (Love's Labour's Lost), Angelo (Measure for Measure), and the title roles in Hamlet and Richard III; also in The Merry Wives of Windsor, Love for Love, Twelfth Night, Julius Caesar, The Cherry Orchard, Othello, The School for Scandal, She Stoops to Conquer, 


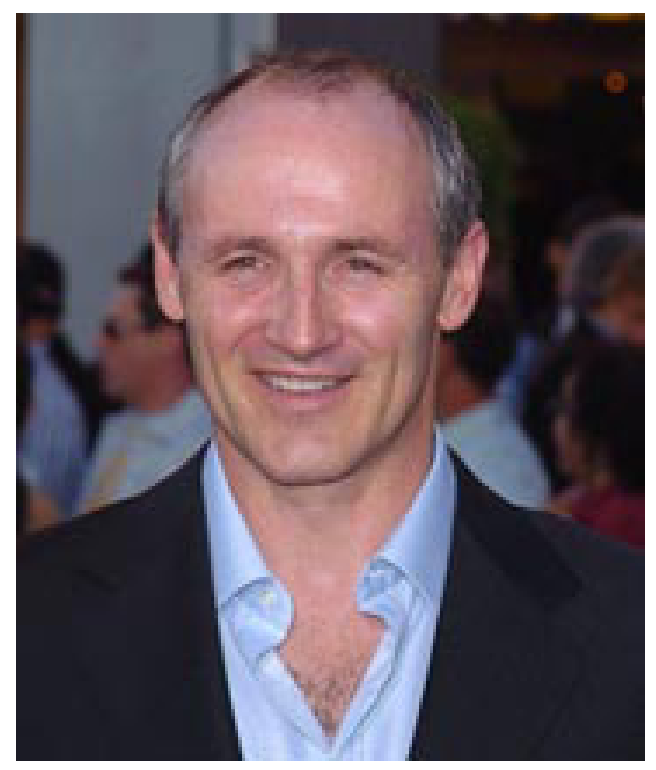

Figure 2: Colm Feore

and many others. He has appeared on the screen in Beautiful Dreamers, Bethune, Iron Eagle II, A Nest of Singing Birds, Skate, Friday the 13th, War of the Worlds, Beyond Reality, and Artemisia.

\section{Author Information}

Gerald PRATLEY, OC, LLD, started his career as film critic with the CBC. In 1969, he founded the Ontario Film Institute which he directed until 1990. He has written several books and numerous articles on film, including Torn Sprockets, a history of Canadian cinema. He taught Film History in universities in Toronto and Waterloo, Canada and holds three honorary degrees from Canadian and US universities.

Gerald A. Pratley (1923-2011) was born and educated in London, England, and came to Canada in 1946. He started working in Toronto for the $\mathrm{CBC}$ as a scriptwriter. He was drawn toward working in motion pictures, and became, in 1948, the CBC's first film critic and commentator.

Gerald Pratley broadcast three programmes a week, Pratley at the Movies, The Movie Scene, Music From the Films, and others, until 1975. During this time he also became the first post-war chairman of the Toronto Film Society, chairman of the Toronto and District Film Council and co-founder of the A-G-E Film Society and correspondent for international magazines such as Films and Filming, Film In Review, Variety, Hollywood Quarterly and International Film Guide. During the 1950s he wrote for Canadian Film Weekly and Canadian Film Digest.

He became known as a speaker on all aspects of motion picture art and industry, and was invited to teach film history at the University of Toronto, York University, University of Waterloo, Seneca College and Ryerson Polytechnical University, with individual lectures being given at many other Canadian and US universities and colleges. He has served as a member of various judging panels of competitions and festivals, being one of the members of the first Canadian Film Awards in 1949.

From 1970 to 1975 he was the director of the Stratford (Ontario) International Film Festival, and from 1969 to 1976 he was Chairman of the International Jury of the Canadian Film Awards. He has attended all the world's leading festivals of film, and in particular, for 30 years, the Cannes Festival as CBC correspondent. He has written six books, The Films of Frankenheimer: Forty Years in Film; The Cinema of John Frankenheimer; The Cinema of Otto Preminger; The Cinema of David Lean; The Cinema of John Huston, and Torn Sprockets, a history of the Canadian cinema. 
Gerald Pratley has served on the Advisory Boards of the film departments of Ryerson Polytechnical University and Humber College, and as a member of the programme committee of TV Ontario. In 1968 he became the founder-director of the Ontario Film Institute of the Province of Ontario, an organization which has distinguished itself in archival holdings and public service and is known since 1990 as the Cinematheque of Ontario. He taught Film History courses at the Department of Film and Photography, Ryerson Polytechnic University, Toronto and the University of Waterloo.

In 1984, Gerald Pratley was made a Member of the Order of Canada and in 2003 Officer of the Order of Canada for his service to Canada through film appreciation. He holds Honorary Degrees in Letters and Fine Arts from York and Waterloo Universities (Ont., Canada) and Bowling Green State University (Ohio, USA).

In 2002, Gerald Pratley received a Special Genie Award from the Academy of Canadian Cinema \& Television in recognition of his lifelong dedication to the promotion and his exceptional support of Canadian cinema.

He died on 14 March 2011 in Ontario, Canada. 